\title{
Chapter 3 \\ Keeping It in the Family: Rotating Chains in Women's Transnational Care Work Between Italy and Ukraine
}

\author{
Svitlana Odynets
}

\subsection{Introduction}

Olena $^{1}$ left for Italy at the age of 51 in 2007 with the goal of saving up to buy a flat for her daughter's family. Before migration, she worked at a big Ukrainian state company and had a high-level managerial position although she did not receive her salary for months. At first, Olena crossed the Italian border as a tourist. As her visa expired after 10 days, she began to search for her first Italian job as an undocumented migrant. Fortunately, a neighbour from Ukraine, whom Olena met by coincidence in the street, knew one Italian family which was looking for a badante (Italian for 'caretaker') for their 90-year-old mother. Olena accepted the offer. She visited her family in Ukraine for the first time 2 years after her initial migration, once she had received an Italian residence permit. After 6 years in Italy, Olena finally bought a flat for her daughter's family and paid for all the necessary renovations there. She is now still working in Italy to buy a flat for herself in Ukraine. However, a few years ago, like some of her other female friends, Olena shifted to working in Italy for periods of 3 months at a time. She now takes turns with another Ukrainian woman who, like her, also wanted to visit home in Ukraine more often. She explains that she does it 'for herself' at the expense of higher earnings. When Olena goes to Ukraine, she has a period of rest in which to renovate her psychological and physical condition. However, she also takes care of her female relatives' children while their mothers work abroad for short periods of time - a new trend facilitated by the lifting of the Schengen visa requirements for Ukrainian citizens in June 2017. Once, Olena looked after her daughter's children while the daughter took off to work in Poland together with her husband. Another time she looked after

\footnotetext{
${ }^{1}$ All migrants' names and other private information have been anonymised

S. Odynets $(\bowtie)$

Independent Scholar, Independent scholar, Lviv, Ukraine

(C) The Author(s) 2021

O. Ryndyk et al. (eds.), Migration to and from Welfare States, IMISCOE

Research Series, https://doi.org/10.1007/978-3-030-67615-5_3
} 
her daughter-in-law's children so that the woman could go with her husband (Olena's son) to the Czech Republic and work there. In the interview, Olena stressed that it is important not only to earn money abroad but also to help the young families to be together, especially when one of the partners (in this case, men) works abroad. Otherwise, as Olena feels, migration would break up families.

Olena's personal story illustrates a new pattern which has recently started taking shape in the transnational space between Ukraine and Italy, countries where persistent deficiencies in the public social-care system perpetuate a traditional gender order in which women, not men, continue to bear the main responsibility for children and elderly care even when they are working and their male partners are not. As Ukrainian female migrants in Italy are getting older (Markov et al. 2009), more and more of them are opting to 'share' their job in Italy with another migrant woman. They not only manage to organise care across the borders through various forms of communication and interactions from a distance (Baldock 2000) - as at the beginning of their migration - but they also create new patterns of short-term transnational mobility within their established long-term migration and expand opportunities for other members of their social networks.

The embedding of social practices in multiple places are widely discussed in migration studies on gender and transnationalism (Baldassar 2007; HondagneuSotelo and Avila 1997; Parreñas 2001). While many studies (Engbersen et al. 2013; Friberg 2012; Zimmermann 1995) often focused more on the patterns of permanent settlement and integration in the destination country, such practices of permanent circulation between two countries were considered mostly as 'incomplete migration' (Okólski 2001). As the transnational approach became more established (Faist 2000; Glick Schiller et al. 1992; Portes 1996), studies emerged showing how migrants settle themselves successfully in mobility (Morokvasić 2004), developing their 'transnational capability' (Ali Ali et al. 2001) and using their mobility as the key social resource in a transnational space. This pattern is not new for Central European female migrants working in Western countries. Bauer and Österle (2016) discuss how middle-aged or older women from Romania and Slovakia commute for care work to Austria and are confronted with care obligations in their countries origin. As Mirjana Morokvasić (2004) shows in her studies on Polish migrant women in Germany, they have also developed a rotational system for living in transnational space. Morokvasić describes how leaving the country becomes a strategy for staying at home (Morokvasić 2004, 11), which is made possible mostly through newly achieved economic and social capital gained in a transnational space. She stresses that the fall of the Berlin Wall for Eastern European women became a new opportunity not only to be 'free to leave' but, more importantly, to be 'free to leave and come back' $(2004,1)$.

However, the essential difference between the abovementioned contexts and Ukrainian women's mobility to and from Italy is that the latter extends beyond EU borders. This significantly undermines their freedom of movement and, consequently, requires another level of reorganisation of their migration experience. The possibility of travelling back is especially important in the case of Ukrainian women migrating to Italy. These women started their migration mostly with the aim - often successfully achieved - of supporting their children financially and paying for their 
university education as well as buying them an apartment (Fedyuk 2011, 2016; Havrylyshyn 2014; Näre 2012; Vianello 2014). However, it has now become clear that they did not return permanently to Ukraine after their goal had been realised. Sabrina Marchetti (2013), discussing self-managed rotations between Ukrainian, Russian, Georgian and Polish migrant women in Italy, underlines that this kind of circularity is neither a preliminary stage to permanent migration nor a consequence of special state programmes but, rather, individual migrant decisions taken with the assistance of migrant personal networks, established relationships with employers and the social and economic capital gained earlier in their migration (Marchetti 2013, 349, 359). What is missing in the article as well as in other studies about short-term transnational mobility within long- established female migration is an analysis of the interrelations between gender, family structures and intra-family care arrangements in connection with the welfare state of both countries.

Therefore, the main objective of this chapter is to trace why and in which ways mature Ukrainian female migrants, with 10-15 years in Italy as domestic workers, invent new ways of knitting together their 'workplace' and their 'home', physically separated between the two countries, instead of settling in Italy permanently or returning to Ukraine for good. This paper also emphasises how they create new economic opportunities for their female relatives, helping them to commodify their reproductive work and accumulate new economic and social capital in this transnational care space.

I start by focusing on the recent changes in the welfare states of Ukraine and Italy, then present the key concepts of my analysis, showing how the logic of the rotational system is, to some extent, predicted by public narratives on the distribution of gender roles in post-Soviet Ukraine. Later I briefly discuss the main costs and benefits for migrant families left behind before, finally, presenting my main empirical cases, where the interviewed women explain why they choose to commute between the two countries more often. I look into their narrative, taking into account the role of migration culture and the inter-generational contract in Ukraine.

\subsection{The Main Features of Ukrainian and Italian Welfare States in the Past Decades}

To some extent, Italy and Ukraine are parts of the same puzzle in terms of the distribution of care responsibilities within society. Italy, as are other Southern European countries, is characterised by a rapidly ageing population and an insufficient social welfare system and has long faced an increasing demand for care for the elderly (Tomassini and Lamura 2009). In the Italian familialistic welfare state (EspingAndersen 1996), the main public expectations and system of care service lay on the shoulders of women, although more and more women participate in the labour market outside the home. Earlier, this demand was met by unmarried women who migrated from southern Italy to the northern parts of the country. However, over the 
past three decades this lacuna has been solved by importing care in the form of immigrant women from the Philippines, Morocco and Eastern and Central European countries. Ambrosini $(2011,36)$ points out that such practices have led to the emergence of an informal welfare state in which Italian families are the main actors hiring new, unregistered migrants and managing their underground work. Significantly, Italy granted the largest number of regularisations in the EU through six amnesties in 22 years (Ambrosini 2011), amnesties which, in fact, enabled the appearance of one of the largest and fastest developing Ukrainian migrant communities in the EU. Today, according to official statistics, about 235,000 Ukrainians live in Italy the fourth largest non-EU immigrant community after Moroccan, Albanian and Chinese citizens (Ministero del Lavoro e delle Politiche Sociali 2018) - of whom, in 2018, 72.3\% held long-term residence permits and $80 \%$ were women. This is the highest share of women among all migrant communities in the country (Ministero del Lavoro e delle Politiche Sociali 2018).

Ukrainian women began migrating to Italy in the second half of the 1990s, under the conditions of protracted economic stagnation, pervasive unemployment and delayed payments of wages due to Ukraine's transition from a socialist planned economy to a market economy. In the 1990s, millions of Ukrainian women and men either lost their jobs or continued to work almost without pay for many months. However, the situation for women was even worse than that of men. Solari (2017) argues that unemployment at that time should be regarded primarily as a gendered issue. With the worsening economy, gender inequality on the labour market of former Soviet countries increased even further, evidenced by the fact that in Russia, for example, women were paid 30\% less than men for the same work (Ashwin 2005). Additionally, with the rapidly falling standard of living and the increasing competition imposed by the 'free market' ideology, many people experienced a sharp psychological crisis - a decrease in social status and a depreciation of the competencies they had acquired in the Soviet system. Therefore, facing unemployment or irregular wages and confronted with an increasingly ineffective social welfare system in their home country, hundreds of thousands of Ukrainian women found migration to Italy to be an attractive option that allowed them to provide a better standard of living for their families and to pay for the education of their children left behind in the country of origin.

The majority of Ukrainian women arrived in Italy in the late 1990s and 2000s on short-term tourist visas and they found themselves in a very vulnerable position. The travelling cost them around US\$ $1500-2500^{2}$ which they paid to unofficial agents and middle-men in exchange for a passport, tourist visa and transport to Italy. Sometimes they also paid for obtaining their first job in Italy, without any official work contract. Over the next 20 years, they have gone from living underground in Italy without any social guarantees, to receiving their legal status and developing established social networks. They have even managed to create the new rotational

\footnotetext{
${ }^{2}$ In comparison, the minimal wage in the year 2000 in Ukraine was US\$ 19 . The money for migration was mostly loaned by relatives and friends who already worked in Italy at that time.
} 
system which allows them to travel to Ukraine more often and to stay much longer than previously. To enable this model within extended families, two major changes in the regularisation system took place. Firstly, in 2007, Italy introduced the National Agreement for Domestic and Care Work, which allowed employers to make one contract with two employees instead of only with one. It began to be used by some Italian families, mainly under pressure from female migrants who, after $10-15$ years working in Italy, wanted to have a more relaxed work schedule. As Marchetti (2013) stresses, both migrant women and employers are satisfied with this pattern. However, it has not become the main pattern and most Italian families still prefer traditional contracts with only one employee (Marchetti 2013, 352). Secondly, in 2017 the Schengen visa regime between EU countries and Ukraine was lifted. Ukrainians now have the right to travel freely to EU countries and stay there without a visa for up to 90 days in any given 180-day period. However, they do not have the right to work in the EU - except in Poland, where foreigners have the right to start to work without a national visa. In fact, the visa-free regime is not the main factor that has made the rotational system in Italian families possible; or the 'rotational' contract to work, both of the women involved need to have legal long-term work permits in Italy. Usually, this type of contract is preferred by women who, as Marchetti (2013) points out, gained sufficient economic and social capital during their long-term migration in Italy. In other words, having a rotational contract is a privilege earned and not a widely accessible work pattern for all Ukrainian female migrants working in Italy.

\subsection{The Rotational Care System}

By and large, the circulation of care is at the centre of women's migration when female migrants from countries with weak welfare systems (Constable 1997; Parreñas 2001) sell their reproductive work to families in developed countries, filling the care gap which is created back at home with the help of their female relatives who remained behind. One could expect that migrant women would see Italy, where they have worked for many years, as the country the most important to them but this is not the case. On the contrary, judging from the analysis of recent trends in this migration, Ukrainian migrant women reinforce their symbolic involvement and physical presence in Ukraine and level it up to balance their role. For the purposes of discussing their involvement in the social context within and across the national borders of both countries, this chapter mobilises the concept of the rotational care system when women begin to substitute for each other in both reproductive and productive work along the borders. 
To analyse the rotational care system involving two or more Ukrainian women ${ }^{3}$ working in shifts for the same Italian family I use Arlie Hochschild's concept of care chains, defined as a 'series of personal links between people across the globe based on the paid or unpaid work of caring' (Hochschild 2000, 131). Helma Lutz and Ewa Palenga-Mölenback (2012) apply the concept to social reproductive work between Ukraine, Poland and Germany. They point out that, when Polish women migrate to Germany, the gap in care responsibilities in Poland is filled by Ukrainian women. However, Ukraine finds itself at the end of the female migrant care chain, as the corresponding care gap left by Ukrainian women migrating to other countries is not filled by women from abroad (Lutz and Palenga-Möllenbeck 2012) but, instead, by their female relatives.

Secondly, I argue that these patterns of care circulating in transnational space between Ukraine and Italy can be seen from an anthropological point of view as a wider inter-generational phenomenon - i.e. the result of complex dynamics in the relationships between different generations of women in Ukraine, as well as of changes in public discourses that were apparent in Ukraine both before and after the collapse of the Soviet Union (Fedyuk 2011; Odynets 2016; Solari 2017; Zhurzhenko 2008).

\subsection{Data and Methods}

This chapter is based on the results of my ethnographic fieldwork conducted in Italy and Ukraine over several phases - in 2012-2013 and 2015 and via Skype in 2019. A total of 45 semi-structured interviews were conducted with Ukrainian women in four Italian cities - Florence, Rome, Padua and Venice. Additionally, in the same period I conducted 20 interviews with family members left behind and with migrants who had returned to Ukraine. The typical settings for the interviews were churches, migrants' homes, schools and the parks where Ukrainians meet up in Italy. The informants came from all parts of Ukraine, were aged from 21 to 67 years and had different social, educational and marital statuses, either with or without children.

This chapter focuses on four migrant stories that demonstrate a new emerging pattern of rotational migration among women with a long work experience in Italy. Among my informants were 51-year-old Olena, who migrated to Italy in 2007 to save up for a flat for her daughter's family, Valentina, 56 years old, who left for Italy in 2008 to earn money to improve her living conditions, Olha, 65, who migrated to earn money for her daughter's university education and Nina who, at 32 years old, came to Italy without any immediate financial need. Nowadays, the first two women take turns with other Ukrainian women who have also worked in Italy over many years, while the two others take shifts with women from their own extended families.

\footnotetext{
${ }^{3}$ It happens more rarely that Ukrainian women work in pairs with a woman from another Eastern European country.
} 


\subsection{Ambivalence and Contradiction in the Gender Contract in Post-Soviet Ukraine}

The main gender contract in the Soviet Union concerned the working mother, who performed a dual function as both a builder of the communist future through her work outside the home and the mother of new generations of workers (Temkina and Rotkirch 2002). The state 'helped' women to perform their task of caring for their children through a wide-ranging socialist support system of kindergartens, free public healthcare and education (Zdravomyslova 2010). After the collapse of the Soviet Union, millions of women found themselves saddled with the same dual burden but with strongly reduced state support (Zdravomyslova 2010). Temkina and Rotkirch (2002) claim that the contract of the working mother did not disappear; instead of state support, women became reliant on the mobilisation of their social networks and relatives. In this manner, the neoliberal project of shrinking state services and benefits has resulted in the 'privatization of motherhood and the transfer of responsibility for reproductive work, once shared with the state, to individual women' (LaFont 2001, quoted in Solari 2017, 34).

The other significant rift appeared in the discursive space. Together with the neoliberal changes in the economy, processes of national revival became highly visible in public debates in the 1990s. A particular place was set aside for the return of the 'traditional Ukrainian family' in opposition to the Soviet family model with the 'working mother' (Fedyuk 2011; Zhurzhenko 2004). According to these new ideas, women were expected to return to the home (Rubchak 2001; Zhurzhenko 2004), as men were considered the main and sole breadwinners in the family. This idea was metaphorically embodied through the cult figure of Berehynia (from the Ukrainian berehty - to preserve; Berehynia literally means a protectress) - 'the great goddess, domestic madonna, hearth mother and today as the nation's mother' (Rubchak 2001, 150). From the early 1990s, Berehynia embodied 'native femininity' (Kis $2005,105)$, the 'proper woman' called to preserve the Ukrainian family as well as the whole nation. Rubchak (2001) shows how the myth of Ukrainian matriarchy takes a variety of forms in the different historical periods in Ukraine and how easily it was activated in post-Soviet Ukraine, 'seducing contemporary Ukrainian women into a false sense of their centrality' (Rubchak 2001, 150). The Berehynia image still plays an important role in migrants' self-representations and self-reflections.

All these economic and discursive transformations mostly hit the generation of middle-aged women, those born in the 1950s and 1960s and raised during the communist rule (Solari 2017). Zhurzhenko (2001) shows that, right after the collapse of the Soviet Union in the early 1990s, these women, being in the heyday of their economically active years, suffered a much stronger economic, social and personal marginalisation than any other social group in Ukraine. Raised according to the values of the Soviet gender contract, they placed much value on being employed. Their sudden unemployment, which hit them shortly after 1991, strongly affected them, as they saw their social status and psychological stability decrease (Ashwin 2000). They did not see themselves as being able to adjust to the new rules of the 
game under 'free market' conditions (Solari 2017; Zhurzhenko 2008). Simultaneously, the family pattern whereby the family lived together with the grandmothers became less popular, despite the social instability discussed above. The symbolical childcare role of the grandmother, which was very important in the Soviet period and the early 1990s was no longer so necessary both because many young mothers, also unemployed, stayed home and took care of their children themselves and because the idea of living together with the grandmother started to lose its attractiveness for many families in post-Soviet Ukraine. The quote below, by 52-year-old Maria, clearly illustrates the conditions under which many Ukrainian women in the 1990s had to make the decision to emigrate to Italy:

I was in a very bad economic situation when I worked in the radio factory and it closed down. In Ukraine, everything was bad, everything was closing. And no money, it was difficult to provide clothes and even food for our children. When I was laid off, I couldn't find a new job, it was suffocating. Later my daughter had a child. I was with them for a while, because she was a student. And we kept this up for ten months. Then we sent my grandson to kindergarten, still without money. When my daughter started her second year at university, I left for Italy and, since then, I have been sending presents and money to Ukraine every month.

Today, among Ukrainian migrant women in Italy, the most numerous are middleaged women who often have grown-up children and grandchildren in Ukraine and who Jennifer Utrata calls 'the real partners of young mothers in post-Soviet space' (Utrata 2008). By the end of 1990s, the average Ukrainian family found itself stuck between new discursive ideals embodied in the national rhetoric and an extremely difficult economic and social situation - with the strong figure of the dual-role grandmother, the vague professional identity of young women/mothers and the somewhat marginalised figure of the father/man, which I discuss in the section below.

\subsection{Responsibilities in a Migrant Family: All the Way around}

Many men also emigrated from Ukraine to provide for their families; however, their migration is accepted in the public discourse as a 'normal' breadwinning activity. Sometimes both partners migrate abroad to earn money for their children, leaving their elderly relatives behind. Moreover, in some families the decisions about migration and how to perform care obligations are made in a mutual agreement between the partners. However, in this section I focus on the men who remain at home in Ukraine without assuming care obligations, whereas their wives work in Italy, because these cases comprise the majority in my fieldwork. For example, 56-yearold Valentyna's experience illustrates a quite typical distribution of care in a migrant family for many Ukrainians. She left for Italy in 2008 at the age of 45 . The reason for her migration was to earn money to buy her brother out from their jointly owned house, as he had sued their mother to split the house and get his share of the money. Valentyna left two children, three and 9 years old, with their father (her husband) 
under the mutual agreement that he would take care of the children. She quickly understood that her partner had betrayed her with another woman and was not looking after the children. She took the children away and left them with her parents. Later, when her parents died, her daughter started to care for her younger brother. Two years ago, having received all the required permits, Valentyna started to work in Italy for shorter periods of 4 months, taking turns with another Ukrainian woman who had been working in Italy for 15 years and who also needed to visit her family in Ukraine more often. Now Valentyna has a goal - to earn money for her son's education. She also said that, when she returns home for 3 or 4 months, conflicts sometimes arise with her daughter about the distribution of responsibilities and the power in the family:

We had a misunderstanding with my daughter, I didn't pay her enough attention. She wanted to have me, not my money. I explained to her that if I hadn't gone, there would have been no money for us. And my son asked me as well: 'Mom, when will you come home and start working here?' I explained to him that I cannot earn here even half the amount I get in Italy. Much has been lost and I would like to hear from our president - how long do we need to work in Italy to be able to return home, to Ukraine, finally? This is very difficult, many families are destroyed.

Despite the expectations of some feminist scholars (Lutz and Palenga-Möllenback 2012) that, as female migrants become the main breadwinners for their families, ideas about gender order will change, the previous gender order inherited by Ukraine from the Soviet era did not relieve the double burden placed on women. Women still embody caregiving - both physically and discursively - and are still seen as responsible for all care drain and care gain, even when they have become the main economic providers for their families. Such expectations are often internalised by the women, as is evident from their narratives and choices related to migration. Thus, migrant women are being blamed for the many divorces and breakups of family relationships, in spite of the reasons and circumstances under which they decided to migrate. However, in many cases female migration could de facto represent grounds for divorce or a desperate solution in the situation where men declare their unwillingness/inability to provide for their families. One of the reasons for this, as illustrated by this quote from Lesia ( 50 years old), could be the allegedly radical transformation of women's capabilities and behaviour after they move abroad for work:

When I went abroad for the first time, I became very independent in problem-solving and earning money, and my husband told me that either I should go back to being the one I used to be, or he would not need me.

Women very often stress their husbands' unwillingness to discuss the migration as a solution for raising the family income and argue that men often prefer to eliminate themselves from family negotiations, as 47-year-old Lesia states:

My husband was left with the children...I went against his will, because I don't know how other men reacted - he didn't want me to go, and he also felt this inability to support the family, and felt this, our family crisis. Later he told me one day that we should not count on him. He didn't let me go voluntarily, but he also did not stop me. 
It is revealing that, in the Ukrainian public discourse, migrant women are expected to be responsible for the husbands they leave behind, for their moral and physical well-being and for the integrity of their family. In numerous interviews during my fieldwork, women expressed their feelings of responsibility (and of guilt) for their husbands who started to drink or experienced personal degradation after their wives' migration. Iryna (54) shows below how, to solve this problem, women organised care for the husbands with the help of their adult children (as a rule, daughters):

When I go home, nothing changes, my husband doesn't touch anything. He has a saucepan and a plate for his own use. And he says he feels bad when I come home. His colleagues come, they drink and sleep in the house, and I am a nuisance in my own home. I plan to return to Ukraine forever in a year. My husband understands that the house is mine too. But he feels better when nobody disturbs him. My daughter goes there to control her father; she knows that when he gets his pension he starts a drinking bout, and there can be intoxication. This situation lasts a week, then everything stabilises.

Strikingly, over the last three decades, no new public discussion has emerged in Ukraine about the necessity of distributing care obligations to other members of society - e.g. fathers or brothers - encouraging them to take over the home tasks of the wives and mothers who have emigrated. Anthropological studies about how Ukrainian fathers and husbands deal with their wives' transnational migration and which personal transformations they are going through are virtually non-existent only the narratives of women are present in current research. One of the reasons for this could be men's unwillingness to talk with other people (i.e. with academic researchers) about their experiences. I can confirm this through my own long experience of trying to recruit men for interviews. I tried to reach them even through their close friends or neighbours but without any success. Summing up, all care responsibilities within migrant families lie on the shoulders of mothers, daughters, other female relatives and sometimes their female friends. It forces them to create their own networks of co-responsibility and cooperation and take turns between paid work and care in order to optimise the emotional and physical costs and benefits of family life.

\subsection{New Forms of Family Mobility Capital}

As in Olena's case, Olha takes turns in working for an Italian family in order to manage her responsibilities towards the family left behind. Olha, who left for Italy 11 years ago to earn money for her daughter's university education, is now 65 years old. After working in Italy for just 2 years, she had earned a sufficient sum of money to achieve her goal. She then returned to Ukraine to live with her husband. Shortly after, the Italian family where she had worked before, called and asked her to come and take care of their older relative. Olha agreed but only on the condition that she would work in short periods of 4 months and return to Ukraine for the same amount of time. The Italian family accepted this proposition. Olha shares her shifts with her brother's wife, who had already worked in Italy for 4 years and who also wanted to 
be more involved now in the life of her family in Ukraine. The women agreed to do shifts every 3-4 months. According to Olha, they both feel that they succeeded in their current situation. This case is an example of migrant empowerment, as it was Olha who demanded (and gained) this flexibility from her Italian employer.

Another informant, 57-year-old Natalia, tells us that, in the beginning, the rotational system allowing women to visit Ukraine more often was only an idea circulated in migrant networks. Later, however, migrants dared to discuss this alternative option with their Italian employers and even suggested that they would look for another Italian family if their requests were not met.

My family where I am working now... At first they didn't even want to hear about it. To have two badante instead of one? It seemed too complicated for them. But I never put my job before my family. I can find another job, but who saves my family for me? Finally they agreed and even wrote the official contract with me. It works well now.

Therefore, having obtained all the official documents and some financial capital, women started to prioritise the needs of their Ukrainian family before those of the Italian one. When Natalia has some holiday time, she goes to the hospital for general treatment because, as she says, her Italian job worsens her health and psychological wellbeing. However, like many other women, she prefers, as she says below, to continue working in Italy until she earns the right to an Italian pension - to which one is entitled at the age of 67 after at least 5 years working and paying taxes regularly:

I do not plan to stop yet because I want to have my pension here, I want to get that. If someone could find a woman who is ready to share shifts with me, I would go to Ukraine more often, it would be very nice for me and my family.

Nina, 32 years old, was the youngest informant I met during my fieldwork. I contacted her after an interview with her mother-in-law, who had been working in Italy for almost 10 years. When Nina gave birth to her child, she stayed at home alone for many days because of her husband's (the child's father) work away from home. Nina's mother-in-law, who is happy to see her first grandson as often as possible, organised shifts with her female friend working in Italy and went to help Nina every 4 months. Nina told me that having the help meant that she started to feel better psychologically and even decided to continue with her education. Now Nina is studying and both women help each other to look after the child. Nina's husband comes home only at weekends because he also works in shifts.

However, most of the women I met during my fieldwork were thinking of creating new economic opportunities for women within the family. As Nina's determination to gain a higher level of education illustrates, the rotational system can enable women to enhance their human capital. Sometimes, the result of these rotations can be a newly achieved personal stability and an increased sense of agency among a woman's female relatives. As long-term migrants come back more often to Ukraine and take on more of the caring responsibilities at home, the other women in the family receive more freedom and space for their own life choices.

Olena Yanevych, the president of the association 'Ukraine Together' in Padua, Italy, explains the rise of the rotational phenomenon and its advantages for Ukrainian 
women; she considers that rotations are actually very interesting, especially if they occur within the same migrant family. She stresses that a woman who goes back home after 3 months in Italy does not need to send money; instead she can take it herself, thus gaining more control over it. In addition, the woman does not lose contact with her husband and children and can look after them not by phone but directly. Further, she can participate in major family events, such as weddings and funerals - something that would have been more difficult under the old, less mobile, paradigm. However, I argue that this new mobility paradigm does not aim to integrate female migrants into the host society but, rather, prepares their return to Ukraine. Olena stresses that the rotational system is so popular that some older women (aged 70 years and above) who had worked as caretakers in Italy for many years and who already hold an Italian permanent residence permit, take their 'turn' as scheduled a year in advance. This perfectly confirms Solari's (2017) point, when she suggested that the reason why migrant mothers consent to such a schedule is not only their altruistic desire to help their children's family. In a situation where they were being doubly marginalised (2018), grandmothers opened up new opportunities for themselves to reclaim their social status and importance in the family - through the re-distribution of care inside the family. In this case, the younger woman receives financial (but not only) help from her mother's remittances and the older woman gains new social dividends in the form of increased personal agency and authority in her extended family. These middle-aged women, who make up the largest group of Ukrainian women in Italy, become simultaneously the main 'breadwinners' and their daughters' 'partners' in the transnational Ukrainian family.

\subsection{Conclusions}

The case of Ukrainian long-term female migration to Italy illustrates the commodification of care taking place both in the employer's family in the country of destination and in their own family back in the home country. Ukrainian women, who initially envisioned their migration to Italy exclusively as a temporary work project, have now found in the rotational system a new way to maintain their presence at the both ends of the transnational space which their migration created. Having access to more private resources - such as personal savings - and benefitting from a slightly stronger institutional framework (increased legalisation, better integration in Italy and improved air and land transportation), they optimise their work schedules in Italy, taking 3- or 4-month turns instead of going abroad for the whole year. They thereby not only continue to play in both fields but also deal better with the formal and private challenges emanating from their long presence in the transnational space and from their long absence from their families back in Ukraine. I have argued that these women circulate care not only within the same nation - Italy - but also sometimes even within the same family, when mothers replace daughters (and the opposite) in 'breadwinner' or 'care provider' roles, thus circulating care transnationally. 
Even though the circulation of care in the transnational Ukrainian family still mostly takes place in the framework of a mother-and-daughter contract, this chapter has presented other cases wherein migrant women are substituted by other female relatives within the extended family or other unrelated female migrants in Italy. The rationale behind these shifts is embedded in the old intergenerational contract within the families and the old gender norms which continue shaping public discourse in the country. One of the main prerequisites for this is that migrant women continue to see themselves as solely responsible for the care and domestic work at home even after many years spent abroad earning a living for their families in Ukraine. They successfully continue to exploit the Berehynia image to justify the moral correctness of their migration decision by emphasising the symbolic and material contributions they have made to their children's (and their families') welfare and wellbeing. As some cases have demonstrated, they also manage to convert this burden of responsibility into new forms of capital and to increase their agency in the transnational space between the two countries.

Acknowledgements I would like to express my gratitude to Mădălina Rogoz, Martina Sekulova, Oleksanr Ryndyk, Brigitte Suter and Gunhild Odden for insightful comments on a previous version of this article. I am also grateful to Nadia Semegen, Vice President of the Ukraine-Florence Association Lilea and Olena Yanevych, President of the association in Padua 'Ukraine Together' both of whom helped me to organise my fieldwork it Italy.

\section{References}

Al-Ali, N., Black, R., \& Koser, K. (2001). The limits to 'transnationalism': Bosnian and Eritrean refugees in Europe as emerging transnational communities. Ethnic and Racial Studies, 24(4), 578-600.

Ambrosini, M. (2011). Undocumented migrants and invisible welfare: Survival practices in the domestic environment. Migration Letters, 8(1), 34-42.

Ashwin, S. (Ed.). (2000). Gender, state, and society in Soviet and post-Soviet Russia. London: Routledge.

Ashwin, S. (2005). 'A woman is everything': The reproduction of Soviet ideals of womanhood in post-communist Russia. In A. Rainnie, A. Smith, \& A. Swain (Eds.), Work, employment and transition (pp. 129-145). London: Routledge.

Baldassar, L. (2007). Transnational families and aged care: The mobility of care and the migrancy of ageing. Journal of Ethnic and Migration Studies, 33(2), 275-297.

Baldock, C. V. (2000). Migrants and their parents: Caregiving from a distance. Journal of Family Issues, 21(2), 205-224.

Bauer, G., \& Österle, A. (2016). Mid and later life care work migration: Patterns of re-organising informal care obligations in Central and Eastern Europe. Journal of Aging Studies, 37, 81-93.

Constable, N. (1997). Maid to order in Hong Kong: Stories of Filipina workers. New York: Cornell University Press.

Engbersen, G., Leerkes, A., Grabowska-Lusinska, I., Snel, E., \& Burgers, J. (2013). On the differential attachments of migrants from Central and Eastern Europe: A typology of labour migration. Journal of Ethnic and Migration Studies, 39(6), 959-981. 
Esping-Andersen, G. (1996). Welfare states without work: The impasse of labour shedding and familialism in continental European social policy. In G. Esping-Andersen (Ed.), Welfare states in transition: National adaptations in global economies (pp. 66-87). London: Sage.

Faist, T. (2000). Transnationalization in international migration: Implications for the study of citizenship and culture. Ethnic and Racial Studies, 23(2), 189-222.

Fedyuk, O. (2011). Beyond motherhood: Ukrainian female labor migration to Italy. Unpublished $\mathrm{PhD}$ thesis. Budapest: Central European University, Department of Sociology and Social Anthropology.

Fedyuk, O. (2016). The gender perspective in Ukrainian migration. In O. Fedyuk \& M. Kindler (Eds.), Ukrainian migration to the European Union (pp. 73-89). Cham: Springer.

Friberg, J. H. (2012). The stages of migration. From going abroad to settling down: Postaccession Polish migrant workers in Norway. Journal of Ethnic and Migration Studies, 38(10), $1589-1605$.

Glick Schiller, N., Basch, L., \& Blanc-Szanton, C. (1992). Towards a definition of transnationalisms: Introductory remarks and research questions. Annals of the New York Academy of Sciences, 645(1), ix-xiv.

Havrylyshyn, P. (2014). Ukrainian labour migration in Italy (1991-2011) [Ukrajinska trudova mihracia v Italii (1991-2011), ukr.]. Kiev: Dyskursus.

Hochschild, A. R. (2000). Global care chains and emotional surplus value. In W. Hutton \& A. Giddens (Eds.), On the edge: Living with global capitalism (pp. 130-146). London: Jonathan Cape.

Hondagneu-Sotelo, P., \& Avila, E. (1997). 'I'm here, but I'm there': The meanings of Latina transnational motherhood. Gender \& Society, 11(5), 548-571.

Kis, O. (2005). Choosing without choice: Predominant models of femininity in contemporary Ukraine. In M. Hurd, H. Carlback, \& S. Rastback (Eds.), Gender transitions in Russia and Eastern Europe (pp. 105-136). Stockholm: Gondolin.

LaFont, S. (2001). One step forward, two steps back: Women in the post-communist states. Communist and Post-Communist Studies, 34(2), 203-220.

Lutz, H., \& Palenga-Möllenbeck, E. (2012). Care workers, care drain, and care chains: Reflections on care, migration, and citizenship. Social Politics, 19(1), 15-37.

Marchetti, S. (2013). Dreaming circularity? Eastern European women and job sharing in paid home care. Journal of Immigrant and Refugee Studies, 11(4), 347-363.

Markov, I., Boyko, Y., Ivankova-Stetsyuk, O., \& Seleshchuk, H. (2009). At the crossroad. Findings of the complex research of the processes of Ukrainian labour migration. Lviv.

Ministero del Lavoro e delle Politiche Sociali. (2018). La comunità ucraina in Italia. Rapporto annual sulla presenza dei migranti. https://www.lavoro.gov.it/documenti-e-norme/studi-estatistiche/Documents/Rapporti\%20annuali\%20sulle\%20comunit\%C3\%A0\%20migranti\%20 in\%20Italia\%20-\%20anno\%202018/Ucraina-rapporto-2018.pdf. Accessed 07 Sept 2020.

Morokvasić, M. (2004). 'Settled in mobility': Engendering post-wall migration in Europe. Feminist Review, 77(1), 7-25.

Näre, L. (2012). Moral economies of reproductive labour: An ethnography of migrant domestic and care labour in Naples, Italy. PhD thesis published by Helsingin Yliopisto. Helsinki: Faculty of Social Sciences, University of Helsinki.

Odynets, S. (2016). Dynamics of life trajectories and social identities of Ukrainian women migrants in Italy [Dynamika zhyttievykh trajectorij i sotsialnykh identychnostei ukrainskykh migrantok v Italii, Ukr.]. unpublished PhD thesis, Stefanyk Precarpathian University, Ukraine. http://chtyvo.org.ua/authors/Odynets_Svitlana/Dynamika_zhyttievykh_traiektorii_ta_sotsialnykh_identychnostei_ukrainskykh_mihrantok_v_Italii/. Accessed 07 Sept 2020.

Okólski, M. (2001). Incomplete migration: A new form of mobility in Central and Eastern Europe. The case of Polish and Ukrainian migrants. In C. Wallace \& D. Stola (Eds.), Patterns of migration in Central Europe (pp. 105-128). London: Palgrave Macmillan.

Parreñas, R. S. (2001). Servants of globalization. Palo Alto: Stanford University Press. 
Portes, A. (1996). Transnational communities: Their emergence and significance in the contemporary world-system. In R. P. Korzeniewicz \& W. C. Smith (Eds.), Latin America in the world economy (pp. 151-168). Westport: Greenwood.

Rubchak, M. J. (2001). In search of a model: Evolution of a feminist consciousness in Ukraine and Russia. European Journal of Women's Studies, 8(2), 149-160.

Solari, C. D. (2017). On the shoulders of grandmothers: Gender, migration, and post-Soviet nation-state building. London: Routledge.

Temkina, A., \& Rotkirch, A. (2002). Soviet gender contracts and their transformations in today's Russia [Sovetskie gendernye kontrakty i ikh transformatsiia v sovremennoi Rossii, Rus.]. Sotsiologicheskie issledovaniia, 11, 4-15.

Tomassini, C., \& Lamura, G. (2009). Population ageing in Italy and southern Europe. In P. Uhlenberg (Ed.), International handbook of population aging (pp. 69-89). Dordrecht: Springer.

Utrata, J. (2008). Babushki as surrogate wives: How single mothers and grandmothers negotiate the division of labor in Russia (Working Paper No. 1). Berkeley: University of California, Program in Soviet and Post-Soviet Studies, Institute of Slavic, East European, and Eurasian Studies.

Vianello, F. A. (2014). Ukrainian migrant workers in Italy: Coping with and reacting to downward mobility. Central and Eastern European Migration Review, 3(1), 85-98.

Zdravomyslova, E. (2010). Working mothers and nannies: Commercialization of childcare and modifications in the gender contract (a sociological essay). Anthropology of East Europe Review, 28(2), 200-225.

Zhurzhenko, T. (2001). Free market ideology and new women's identities in post-socialist Ukraine. European Journal of Women's Studies, 8(1), 29-49.

Zhurzhenko, T. (2004). Strong women, weak state: Family politics and nation building in postSoviet Ukraine. In K. Kuehnast \& C. Nechemias (Eds.), Post-Soviet women encountering transition (pp. 23-43). Baltimore: Johns Hopkins University Press.

Zhurzhenko, T. (2008). The gendered markets of Ukraine: The political economy of nationbuilding [Gendernyye rynki Ukrainy: politicheskaya ekomomiya natsionalnogo stroitelstva, Rus.]. Vilnius: European Humanities University.

Zimmermann, K. F. (1995). Tackling the European migration problems. Journal of Economic Perspectives, 9(2), 45-62.

Open Access This chapter is licensed under the terms of the Creative Commons Attribution 4.0 International License (http://creativecommons.org/licenses/by/4.0/), which permits use, sharing, adaptation, distribution and reproduction in any medium or format, as long as you give appropriate credit to the original author(s) and the source, provide a link to the Creative Commons license and indicate if changes were made.

The images or other third party material in this chapter are included in the chapter's Creative Commons license, unless indicated otherwise in a credit line to the material. If material is not included in the chapter's Creative Commons license and your intended use is not permitted by statutory regulation or exceeds the permitted use, you will need to obtain permission directly from the copyright holder.

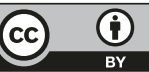

